УДК 37.011(092):373.035

DOI:

Світлана Бобела, аспірант кафедри соичіальної педагогіки та корекиійної освіти Дрогобииького державного педагогічного університету імені Івана Франка

\title{
ВПРОВАДЖЕННЯ ІДЕЙ СОЦІАЛЬНОГО ВИХОВАННЯ АВГУСТИНА ВОЛОШИНА В УМОВАХ СУЧАСНОЇ ЗАГАЛЬНООСВІТНЬОЇ ШКОЛИ
}

Автором окреслено основні положення концепиії соціального виховання Августина Волошина, проаналізовано праці “Загальна педагогіка", “Дидактика", “Педагогічна психологія”, “Методика”, "Педагогіка і дидактика", “Історія педагогіки”, “О соціальном вихованню”, "Наш страшний ворог”, “Читанка для угро-русской молодежи”. Доведено доцільність використання ідей видатного педагога у практику соціального виховання учнів в умовах загальноосвітньої школи.

Ключові слова: Августин Волочин; виховання; сочіальне виховання; школа; учнівська молодь. Лim. 10.

Svitlana Bobela, Postgraduate Student of the Social Pedagogy and Correctional Education Department Drohobych Ivan Franko State Pedagogical University

\section{IMPLEMENTATION OF SOCIAL EDUCATION IDEAS OF AVHUSTYN VOLOSHYN IN THE CONDITIONS OF MODERN SECONDARY SCHOOL}

The author outlines the main provisions of the concept of social upbringing by Avhustyn Voloshyn in the works: "General Pedagogy", "Didactics", "Pedagogical Psychology", "Methodology", "Pedagogy and Didactics", "History of Pedagogy", "Social Education”, "Our Terrible Enemy" and "Reader for Hungarian and Russian Youth", "Pedagogical methodology". It is proved that the pedagogical experience of Avhustyn Voloshyn made a significant contribution to the development of the theoretical and practical foundations of social education, and the return to the sources of his pedagogical heritage is an attempt to look at the modern problems of social education through the prism of time.

The article states that the achievement of the goal of social upbringing of pupils involves the orientation in certain areas: national, moral-religious, mental, physical, labor and aesthetic.

The peculiarities of introduction of ideas of the teacher concerning prevention of alcoholism in the practice of social education of pupils in the conditions of a secondary school are analyzed. It is substantiated that they can be reflected in the attraction of student youth to the self-produced booklets aimed at promoting healthy lifestyles; the preparation of teachers, social educators / social workers for presentation at the presentation of this topic.

It is argued that the inclusion of the ideas of social education of Avhustyn Voloshyn in the context of socio-pedagogical practice, the orientation towards the socio-educational competence of representatives of the socio-occupational professions (teachers, social educators / social workers, educators of educational institutions of different types, etc.) is a necessity of constant theoretical and practical comprehension of problems of social education.

Keywords: Avhustyn Voloshyn; upbringing; social upbringing; a school; pupils'youth.

П остановка проблеми. Становлення України як незалежної держави, виникнення нових політичних, економічних та соціальних основ їі розвитку вимагає розв'язання актуальної проблеми побудови нових взаємин між особистістю та суспільством. Пошук раціональних шляхів соціалізації особистості, її соціальний захист стають невідкладними питаннями людинознавчих дисциплін.

Надзвичайно важливим $є$ вирішення питання про суб' єктів соціально-педагогічної роботи, котрі здійснюють соціальне виховання. Основними інститугами соціального виховання $\epsilon$ сім'я, родичі, найближче оточення дитини, школа, формальні та неформальні організації та ін. Необхідно зауважити, що соціальне виховання, як найважливіший компонент освітнього процесу має важливе значення для становлення особистості, готовності іiі до самостійного життя, має реалізовуватися в іiі інтересах і не завдавати шкоди розвитку.

Сучасна ситуація в нашій країні характеризується інтенсивним пошуком шляхів оновлення ії змісту, розробкою оригінальних форм і методів виховання та навчання, використання нових форм організації педагогічного процесу, відкритістю та глибоким інтересом учених та педагогів-практиків до ідей не тільки сучасних учених, але й педагогів минулого [6].

Знання педагогічної спадщини минулого $є$ надійним джерелом розвитку сучасної системи виховання. До плеяди відомих українських педагогів першої половини ХХ століття 


\section{ВПРОВАДЖЕННЯ ІДЕЙ СОЦАЛЬНОГО ВИХОВАННЯ АВГУСТИНА ВОЛОШИНА В УМОВАХ СУЧАСНОЇ ЗАГАЛЬНООСВІТНЬОЇ ШКОЛИ}

відносимо Августина Волошина - визначного вченого, педагога, громадського, культурного й церковного діяча Закарпаття, президента Карпатської України, який усю свою творчу спроможність віддав українському народові, його духовним устремлінням до кращої долі, свободи і щастя.

Аналіз останніх досліджень і публікацій. Ідеї соціального виховання сучасної учнівської молоді висвітлено у наукових доробках Л. Коваль [6], I. Ковальчук [7], І. Звєрєва [6], А. Рижанова [9], С. Хлєбік [6] та ін.

Різні аспекти концепції соціального виховання висвітлено у багатому науково-педагогічному та публіцистичному доробку видатного педагога. Це, зокрема такі його праці, як “Загальна педагогіка”, “Дидактика”, “Педагогічна психологія", “Методика”, “Педагогіка і дидактика”, “Історія педагогіки” тощо. Разом із тим найбільш повно і докладно основні положення педагогічної концепції А.Волошина представлені у його праці “О соціальном вихованню” [1], де він на широкому історикопедагогічному матеріалі дає грунтовний аналіз різних поглядів на сутність і цілі соціального виховання та на основі цього презентує власне бачення змісту, мети, методів та засобів соціального виховання, ролі соціальних інституцій у соціальному становленні та підготовці до самостійного життя учнівської молоді.

Виклад основного матеріалу. Здійснений нами аналіз становлення та розвитку педагогічних поглядів Августина Івановича Волошина на соціальне виховання у контексті його культурноосвітньої, літературної, громадсько-політичної діяльності та на основі науково-педагогічних праць видатного педагога дозволяє нам окреслити розроблену ним концепцію соціального виховання учнівської молоді, яка була не тільки теоретично обгрунтована, але й багатогранною освітньою діяльністю впроваджена ним у виховний процес в цих складних історичних умовах Закарпаття.

У центрі концепції і головним об’єктом соціального виховання за А. Волошиним перебуває дитина 3 властивими їй вродженими задатками, здібностями, талантами. При цьому головним завданням виховання, на переконання педагога, $є$ забезпечення розвитку цих чинників, формування національно свідомої, гуманної, соціально зрілої, творчої і працелюбної особистості, здатної до свідомого суспільного вибору й збагачення інтелектуального, духовного й культурного потенціалу свого народу. Разом із тим об'єктом соціального виховання у педагогічній концепції А. Волошина, окрім дитини, учня, виступає і доросле населення Закарпатського краю, насамперед батьки учнівської молоді, які, на його переконання, тільки будучи прикладом для своїх дітей, здатні забезпечити їх повноцінний всебічний розвиток. 3 огляду на це особливого значення він приділяе психолого-педагогічній просвіті батьківської громадськості через спеціально організовані заняття для них, відкриття читалень, ознайомлення $з$ популярною літературою, що друкувалась на сторінках педагогічних журналів і газет, а також літературними творами соціальновиховного характеру. Дієвим шляхом просвітницької діяльності вважав він і перегляд вистав, які демонструвалися акторами аматорських театрів. Більше того, до усієї цієї діяльності Августин Волошин долучався особисто і як педагог-практик, i як публіцист і літератор, $\mathrm{i}$ як громадський діяч.

Наголошуючи на тому, що соціальне виховання покликане “передавати культуру чим ширшим кругам людства”, видатний педагог зазначає, що “кождоє доброє виховане повинно бити и соціальноє, головну характеристику котрого можеме виразити словом altruizma, любви ко ближним" $[1,10]$.

В аспекті сказаного цілком очевидно, що майбутнє нашої країни залежить від того, якими якостями будуть наділені молоді люди, рівнів їхньої вихованості та освіченості, готовності до самостійного усвідомленого соціального та політичного вибору тощо. Ці та інші якісні характеристики особистості молодої людини особливо є затребуваними сучасним станом соціокультурного життя країни.

Загальновизнаним є той факт, що надзвичайно значущою є та обставина, що за останні роки у вихованні учнівської молоді посилилася його соціальна акцентуація, орієнтація на соціальне замовлення.

При цьому особливого значення набуває оновлена парадигма розвитку шкільної освіти, що знаходить свій прояв у статусі соціального виховання як найважливішого пріоритету в освіті учнівської молоді, систематичному та цілеспрямованому впливові на духовний, інтелектуальний, моральний, фізичний, естетичний розвиток. Одночасно змінюються способи організації навчально-виховного процесу: розвиток отримують варіативність освіти, соціально-педагогічні технології та інші.

Ми поділяємо думку сучасної дослідниці А.О. Рижанової, що “у процесі соціального виховання необхідно створювати умови 


\section{ВПРОВАДЖЕННЯ ІДЕЙ СОЦІАЛЬНОГО ВИХОВАННЯ АВГУСТИНА ВОЛОШИНА В УМОВАХ СУЧАСНОЇ ЗАГАЛЬНООСВІТНЬОӤ ШКОЛИ}

“переходу” соціального суб'єкта від однієї форми соціальності до іншої (наприклад, від сімейної до національної), тобто гальмувати абсолютизацію цінностей будь-яких соціальних суб'єктів, соціумів, долаючи егоїзм особистісний, віковий, сімейний, національний, расовий, конфесійний, професійний, регіональний тощо" [9].

Педагогічний досвід Августина Волошина зробив чималий внесок в розробку теоретичних та практичних засад соціального виховання, а повернення до джерел його педагогічної спадщини є спробою подивитися на сучасні проблеми соціального виховання крізь призму часу.

Мета соціального виховання учнівської молоді в умовах загальноосвітньої школи полягає у забезпеченні найбільш сприятливих умов для повноцінної самореалізації, саморозвитку конкретної особистості, іiі самоактуалізації в найближчому оточенні, в передачі соціального досвіду від покоління до покоління; в створенні виховуючого соціального середовища в найближчому оточенні особистості; у формуванні соціально значущих орієнтацій і цінностей; у подоланні соціальних відхилень, забезпеченні соціально-педагогічної підтримки і захисту дітей, подолання соціальної дезадаптації.

Досягнення мети соціального виховання учнівської молоді передбачає орієнтування на певні напрямки: національне, морально-релігійне, розумове, фізичне, трудове та естетичне. Ефективна реалізація соціального виховання на практиці вимагає врахування специфічних принципів: гуманізму, демократизму, народності, природовідповідності, культуровідповідності, соціальної обумовленості виховання, особистісно орієнтованого підходу. Важливим є вибір методів i засобів впливу на соціальне виховання особистості.

Вплив на соціальну поведінку зумовлений широким спектром соціальних взаємодій, в різних умовах соціального середовища. Створення сприятливого середовища соціального виховання в умовах загальноосвітньої школи передбачає налагодження чіткої системи взаємодії між об'єктами та суб'єктами соціально-педагогічної роботи на основі співпраці, співтворчості тощо; мотивації учнівської молоді до саморозвитку, самовдосконалення.

Засобами та методами впливу на особистість $€$ позитивний досвід поведінки, приклад батьків; учнівське самоврядування; вплив вчителя на учнів; прищеплення християнських цінностей.

Ми погоджуємося із сучасною дослідницею I.Ковальчук, котра запевняє, що у набутті позитивного соціального досвіду важливу роль грає добре налагоджений побут школи, який припускає просторі, добре освітлені, затишні класи; наявність у школі єдиного режиму, традицій, системи самообслуговування, єдиної шкільної форми або елементів їі $[7,126]$.

Школа слугує субстанцією для передачі знань, формування умінь, навичок і соціального досвіду учнів. Звідси робимо висновок, що рольовий статус соціального виховання вимагає професійної підготовки суб'єктів, відповідальних за його реалізацію. У контексті сказаного нагадаємо, що видатний педагог радив учителеві заводити особистий архів кожної дитини. Проводячи паралель із сучасними умовами роботи 3 дітьми в умовах загальноосвітньої школи доходимо висновку, що й сьогодні особливо важливим $є$ грамотне складання соціальних паспортів (дитини, класу). Аналіз сучасних соціальних паспортів у різних школах доводить необхідність ïх доповнення такими даними про дитину як от: душевні властивості (інтелігентність, увага, інтереси, пам'ять, сугестивність, стомлювання, фантазія, словесний запас, релігійна приналежність тощо; оточення (релігійна приналежність батьків, піклування батьків про дитину, їхні соціальні відносини, ставлення дитини до школи, вчителя, батьків $[5,67]$.

Розглядаючи роль даного соціального інституту у становленні особистості, А.Волошин окреслив умови його ефективного функціонування, серед яких тісний контакт, взаєморозуміння і спільна трудова діяльність батьків і дітей; тепла, доброзичлива атмосфера рідного домута сумлінне виконання батьківських обов'язків; позитивний приклад і авторитет батьків; народні традиції мудрої любові до дітей, поєднані з розумною вимогливістю до них; знання батьками вікових особливостей розвитку дитини та застосування на підставі цього відповідних засобів та методів виховного впливу, спрямованих на всебічний розвиток дитини тощо [2, $12-15]$.

Августин Волошин вважав однією 3 найголовніших рис культури вчителя справедливість. "Виховуємо дитину, - писав він, нашим добрим прикладом і справедливим супроти неї поступуванням" [5, 67]. Вважаємо, що дисциплінованість учнів - $є$ підгрунтям для формування соціальної поведінки. Про особливе ставлення Августина Волошина до цієї проблеми свідчить оповідання “Добрий учень”, яким починається “Читанка для угро-русской молодежи”: “Добрий учень приходить в школу завжди вчасно. Він не розмовляє з товаришами в час науки. Він слухає уважно пояснення вчителя. 


\section{ВПРОВАДЖЕННЯ ІДЕЙ СОЦАЛЬНОГО ВИХОВАННЯ АВГУСТИНА ВОЛОШИНА В УМОВАХ СУЧАСНОЇ ЗАГАЛЬНООСВІТНЬОЇ ШКОЛИ}

Він належно готує кроки, тримає в порядку свої учбові речі і не “казить” свої книги” $[10,3]$.

В умовах сьогодення, на жаль, не втрачають погляди Августина Волошина на антиалкогольне виховання дітей. Так, у праці “Наш страшний ворог” описуються причини та наслідки алкоголізму й пияцтва; автор наводить аргументовані докази наслідків жіночого алкоголізму. Туг подаються малюнки серця та печінки здорової людини іп'яниці; малюнки - де демонструється пагубний вплив алкоголю на дітей [4].

А. Волошин вважав, що саме школа за підтримки батьків повинна стати ініціатором антиалкогольної пропаганди, яка, на його переконання, повинна починатися вже у молодшому шкільному віці. А, отже, не випадково у “Читанці для II і III класів народних шкіл” (1925) він подає наступні тексти: “Здоровє”, “Сокоти здоровє!”, “Сокотися од паленки”, “Пянство (По Духновичу)”, в яких розкривається значення здоров'я для людини, пагубний вплив пияцтва не тільки на здоров'я, а й соціальне становлення особистості, їі ціннісний світ, ставлення до неї оточуючих: "Пянство, то есть великий гръх, Соблазнь у людей и посмъх. Пьяный въ душъ не жиє И скотови ровный е! Пьяный розум утрачає И о Бозъ забуває. Нич он добро не чинить, Лиш, як свиня, так лежить. Паленка то подлый напой. Яд - то тълу, душъ нашой. И кто любить пити, Довго не буде жити" [3, 78]. Звертаючись до молодших школярів цими рядками 3 вірша Духновича “Пьянство”, А.Волошин спонукав їх замислитися над питаннями сенсу життя, допомагав зробити правильні висновки, що зловживання алкоголем не тільки губить людину, але й $є$ великим гріхом. Цілеспрямовано дана проблема піднімається і в інших працях видатного педагога. Так, зокрема, у праці "Наш страшний ворог” (1918) автор популярно у доступній формі висвітлює причини і наслідки алкоголізму, підкріплюючи свої слова наочністю - малюнками, які демонструють пагубний вплив алкоголю на дітей, пропонує порівняти малюнки серця та печінки здорової людини і п'яниці [4].

Питання соціального виховання учнівської молоді стали сьогодні предметом уваги не лише школи та батьків, ця проблема, з огляду на свою актуальність, знайшла відображення і у низці державних документів, програм профілактики наркотичних та алкогольних проблем. Так, Комплексна програма 3 профілактики наркотичних та алкогольних проблем, зорієнтована на учнів 1 - 11 класів, їх батьків та персонал загальноосвітніх закладів I - III ступенів навчання представлена такими модулями:
- Модуль 1. Технологія проведення профілактичного тренінгу в умовах шкільного середовища.

- Модуль 2. Профілактичні дії на робочому місці серед персоналу загальноосвітніх навчальних закладів.

- Модуль 3. Батьківська компетентність або підказки батькам.

- Модуль 4. Моє здоров'я... Моє рішення... Мій вибір...

У програмі зазначено, що 3 метою вдосконалення профілактичної діяльності щодо вживання алкоголю та наркотиків держава сприяє:

- розповсюдженню інформації про шкоду, яку алкоголь та наркотики можуть завдати здоров'ю та життю окремих осіб, сімей, громади та спільнот, суспільства в цілому, використовуючи для цього заходи громадської просвіти або засоби масової інформації;

- проведенню кампаній у засобах масової інформації з тим, щоб посилити серед громадськості підтримку існуючих або нових стратегій, які направлені на зменшення тієї шкоди, що може бути нанесена вживанням алкоголю та наркотиків;

- наданню всім молодим людям можливості отримати орієнтовану на набуття навичок освіту в рамках інтегрованої та цілісної програми протиалкогольної та протинаркотичної просвіти, що базується на принципах створення безпечного та сприятливого для здоров'я середовища, використовуючи дозволені державою форми та методи проведення цієї роботи;

- забезпеченню того, щоб протиалкогольна та протинаркотична просвіта (починаючи 3 дошкільного рівня), була включена в навчальні програми дошкільних та шкільних установ одночасно 3 відповідними навчальними програмами для батьків [8].

Ідеї праць Августина Волошина можуть знайти своє відображення у залученні учнівської молоді до самостійного виготовлення буклетів, спрямованих на пропагування здорового способу життя; підготовці вчителями, соціальними педагогами/соціальними працівниками презентації при поданні цієї теми.

Висновки. Включення ідей соціального виховання Августина Волошина в контекст соціально-педагогічної практики, орієнтація на соціально-виховні компетенції представників соціономічних професій (вчителів, соціальних педагогів/соціальних працівників, вихователів педагогічних установ різного типу тощо) підкреслює нагальну необхідність постійного теоретичного і практичного осмислення проблем соціального виховання. 


\section{ВПРОВАДЖЕННЯ ІДЕЙ СОЩАЛЬНОГО ВИХОВАННЯ АВГУСТИНА ВОЛОШИНА В УМОВАХ СУЧАСНӦ̈ ЗАГАЛЬНООСВІТНЬОӤ ШКОЛИ}

\section{ЛIТЕРАТУРА}

1. Волошин А.І. О соціяльном выхованю / Августин Волошин. - Ужгород: “Уніо”, 1924. $53 \mathrm{c}$.

2. Волошин А. Загальна педагогіка / Августин Волошин. - Ужгород: Накладом педагогічного товариства Підкарпатської Руси, 1932. - 24 с.

3. Волошин А. Мала читанка для II и III класы народных школ / Августин Волошин. - Ужгород: Уніо, 1925 - 125 c.

4. Волошин А. Наш страшний ворог / Августин Волошин. - Унгваръ.: друкарня акційного тов.ва "Уніо", 1918. - 32 с

5. Волошин А. Педагогічна методологія. Книга 1. Методологія навчання: Для вчителів та вчительських семінарій / А. Волошин. - Прага: "Пробоєм", 1943. - 206 с.

6. Коваль Л.Г. Соціальна педагогіка/Соціальна робота: навч. посібн. / Л.Г. Коваль, І.Д. Звєрєва, С. Р. Хлєбік. - К.: ІЗМН, 1997. - 392 с.

7. Ковальчук I. А. Соціальне виховання як цільова функція школи / І. А. Ковальчук // Вісник Луганського національного університету імені Тараса Шевченка. Педагогічні науки. - 2012. № 19 (3). - С. 123 - 127.

8. Комплексна програма 3 профілактики наркотичних та алкогольних проблем, зорієнтована на учнів 1-11 класів, їх батьків та персонал загальноосвітніх закладів I - III ступенів навчання. Технологія проведення профілактичного тренінгу в умовах шкільного середовища. Профілактика алкогольних та наркотичних проблем. Модуль 1.: Навчально-методичний посібник / Вієвський А. М., Лепеха К. І., Балакірєва О.М., Дивак В.В., Дмитришина Н.А., Жданова М.П., Олійник І.М., Панок В.Г., Сидяк С.В. - Київ, 2014. - 60 с.

9. Рижанова А.О. Розвиток соціальності в культурі інформаційного суспільства / А.О. Рижанова: Електронний ресурс: http://www.nbuv.gov.ua/ old_jrn/Soc_Gum/Pipo/2012_36/12raocis.pdf

10. Читанка для угро-русской молодежи / сост. Августин Волошин. - Ч 1. Для низших классов народних школ. - Унгваръ: Изданіе акційного общества “УНІО”, 1904. - 240 с.

\section{REFERENCES}

1. Voloshin, A.I. (1924). O sotsiialnom vykhovaniu [On Social Education]. Uzhgorod: Uni, 53 p. [in Ukrainian].

2. Voloshin, A. (1932). Zahalna pedahohika [General pedagogics]. Uzhgorod: An Excess of the
Pedagogical Society of Subcarpathian Rus, 24 pp. [in Ukrainian].

3. Voloshin, A. (1925). Mala chytanka dlia II y III klasy narodnykh shkol [Small reader for II and III classes of folk schools]. Uzhgorod: Unio, 125 p. [in Ukrainian].

4. Voloshin, A. (1918). Nash strashnyi voroh [Our terrible enemy]. Ungvar: Printing house of the stock company "Uni", 32 p. [in Ukrainian].

5. Voloshin,A. (1943). Pedahohichna metodolohiia. Knyha 1. Metodolohiia navchannia: Dlia vchyteliv ta vchytelskykh seminarii [Pedagogical methodology. Book 1. Methodology of Teaching: For Teachers and Teachers Seminars]. Prague: "Breakthrough", 206 pp. [in Ukrainian].

6. Koval, L.G., Zvereva, I.D. \& Khlebik, S. R. (1997). Sotsialna pedahohika.Sotsialna robota: navch. posibn. [Social pedagogy]. Kyiv: IZMN, 392 p. [in Ukrainian].

7. Kovalchuk, I. A. (2012). Sotsialne vykhovannia yak tsilova funktsiia shkoly [Social education as the target function of the school]. Visnyk of Lugansk National Taras Shevchenko University. Pedagogical sciences,no. 19 (3), pp. 123-127. [in Ukrainian].

8. Vievsky, A.M., Lepeha, K. I., Balakireva, O.M., Divak, V.V., Dmitrishina, N.A. \& Zhdanova, M.P. et al (2014). Kompleksna prohrama z profilaktyky narkotychnykh ta alkoholnykh problem, zoriientovana na uchniv 1-11 klasiv, yikh batkiv ta personal zahalnoosvitnikh zakladiv I - III stupeniv navchannia. Tekhnolohiia provedennia profilaktychnoho treninhu $v$ umovakh shkilnoho seredovyshcha. Profilaktyka alkoholnykh ta narkotychnykh problem. Modul 1. [Comprehensive program for the prevention of narcotic and alcoholic problems, oriented towards pupils of grades 1-11, their parents and staff of general educational institutions of I-III levels of study. Technology of carrying out preventive training in the conditions of the school environment. Prevention of alcohol and drug problems. Module 1.: Educational and methodical manual]. Kyiv, 60 p. [in Ukrainian].

9. Ryzhanova, A.O. (2012). Rozvytok sotsialnosti $v$ kulturi informatsiinoho suspilstva [Development of sociality in the culture of the information society]. [Electronic resource] http://www.nbuv.gov.ua/old_jrn/ Soc_Gum/Pipo/2012_36/12raocis.pdf[in Ukrainian].

10. Chytanka dlia uhro-russkoi molodezhy(1904). [Reader for Hungarian and Russian youth]. (Ed.).Augustine Voloshin, part 1. For elementary schools of public schools. Ungvar: Publishing house of the public company "UNIO", 240 p. [in Ukrainian].

Стаття надійшла до редакції 05.03.2018 